\title{
Bridging the Gap: Discourse in Text-Based Foreign Language Classrooms
}

\author{
Miguel Mantero \\ The University of Alabama
}

\begin{abstract}
:
This study investigated text-centered talk in an "Introduction to Hispanic Literature" universitylevel classroom. The study was framed within sociocultural theory (Vygotsky, 1978; Wertsch, 1986, 1991) and attempted to establish the nature of classroom talk in the college-level foreign language "bridge course." The study also aimed to clarify the relationship between cognitive processes and language acquisition in a foreign language course. Student-initiated talk or opportunities for discourse were observed in relation to those opportunities recognized or provided by the instructor. The data was analyzed according to the level of talk (utterance, dialogue, discourse) and the level of cognition of the students' responses. This analysis characterized text-centered talk in the university-level foreign language classroom as mainly teacher-centered, studentsupported dialogue that did not take advantage of the majority of opportunities for extending classroom talk into the discourse level. Representative samples of the collected data are provided to support the findings of the study.
\end{abstract}

\section{Introduction}

The analysis of classroom talk has helped shape current classroom pedagogical practices, curriculum development, and theories of second language acquisition (SLA). Most studies on classroom talk that use a sociocultural framework focus on interaction among students, viewing the instructor in the peripheral role of establishing the task and monitoring student progress.

A primary aim of this study was to investigate text-based foreign language classrooms (FLCs) to determine if or how instructors encourage students to interpret and use their own experiences in understanding course literature and authentic texts (thus becoming "experts" in their own right) and to develop cognitive abilities that help them increase their language skills. Moreover, the role of authentic readings and literature and their effects on discourse in the FLC have not been fully understood within a sociocultural framework. This study centered on a fourth-semester FLC in which literature and authentic texts were introduced as a basis for developing discourse.

\section{Review of Previous Research}

The study of discourse in the FLC has always been an influential but divisive area for scholars and students. Some understand classroom discourse as revolving around the instructor, but others believe that classroom discourse revolves around issues and ideas, not individuals.

Studies investigating classroom talk (Aljaafreh \& Lantolf, 1994; Gass \& Varonis, 1994; Hall, 1995; Long \& Porter, 1985) have usually focused on elements that affect overall classroom dis-

Miguel Mantero (PhD, The Florida State University) is Assistant Professor of Foreign Language and ESL Education at the University of Alabama. 
course, centering on the students. Few articles addressing the teaching of literature in foreign language courses have dealt with text-based discourse or the instructor's role in helping students develop the cognitive processes that will allow them to increase their proficiency in the second language.

Previous studies have examined "task-completion" (tasks that instructors have designed) by the students, focusing on student interaction. However, in a FLC that uses literature as the focus for discourse, the instructor rarely provides tasks for the students to perform, only interpretations or reactions to the readings (Knutson, 1993; Littlewood, 1980; Steiner, 1970).

Davis et al. (1992) studied the attitudes of foreign language students toward literature and found that they were virtually nonexistent, much less than positive. Davis et al. concluded that enrollment dropped dramatically between "language-based" and "literature-based" courses. They suggested that the teaching styles used in literaturebased courses were partly to blame for this dramatic decrease in student participation in upper-level second language programs.

The act of defining and lexical linking (Hall, 1995) talking about words and using them to drive the classroom talk lexically as opposed to conceptually - is often misunderstood for "discourse" in an FLC. To the contrary, discourse is conceptually based and not lexically based. For example: A student enters into an exchange on the definition of the word "libertad" with the instructor. The instructor then answers, "freedom." This simple dialogue, based on the utterances of "What is "libertad"?" and "It is freedom," may inform the individual about the definition of the word without entering into a discussion about it (such a discussion could include, e.g., the price of freedom or who in the world really has freedom). In a classroom where the focus is not solely on building vocabulary but on improving conversation and reading skills, lexical linking does little to assist the development of discourse in the FLC, according to Hall (1995).

Literature-based FLCs should focus on the works read and their meanings to readers (Rosenblatt, 1938), not just on the definitions that assist in interpretating the works. However, research on communication in literature-based FLCs has often not moved beyond the utterance or dialogue level, focusing instead on lexical linking as defined here.

\section{Theoretical Framework}

Vygotsky (1978) believed that the human mind is, in essence, mediated by the contexts of our daily lives. Mediation, Lantolf (Lantolf \& Appel, 2000) agrees, centers around the notion that humans use language and other symbolic tools to interact indirectly with their environ- ments - that speech is the primary tool for mediating the human mind.

Vygotsky also made certain assertions as to speech and thought. He believed, as does Lantolf, that speaking and thinking are different concepts that deserve to be treated differently. In developing the sociocultural view of human learning, Wertsch (1998) underscores the importance of focusing on "tool use," in the sense used by Lantolf. Both Lantolf and Wertsch refine Leontiev's (1978) belief that to understand the activity of the human mind in a sociocultural light, we must take a closer look at tool-mediated, goal-directed action.

Sociocultural theory also derives from Luria's (1981) belief that the mind is mainly developed as a functional aspect of culturally and socially constructed human behavior. Leontiev expanded Luria's understanding, stating that motivation is an important factor in whether or a not a person appropriates understanding or knowledge.

Volosinov (1973) described the essence of the purpose of language in an FL classroom, as seen through sociocultural theory, as production. The primary tools in the FL classroom are words (language), which assist in mediating the discourse and activity of those (the learners) participating in goal-directed action, who use them.

Sustained classroom talk is defined according to Vygotsky's theory (1962), which states that learning through meaningful interaction with one's environment and the people within it are essential to the development of new knowledge. Rosenblatt (1938) foreshadowed Vygotsky's ideas by stating that transaction is an active relationship that the reader and the literary text share in the creation of meaning. Rosenblatt emphasizes this process as a "two-way" transaction that is related to Vygotsky's views about learning through meaningful interaction. In Rosenblatt's transactional theory, the reader and the literary text share a distinct, reciprocal relationship. Rosenblatt's views fall under the category of reader-response theory and go against the grain of tradi-

Table 1

CLASSROOM ACTIVITY OUTLINE

General Announcements and Duties: 5 minutes

Vocabulary and Prereading: 10-15 minutes

Text-Centered-Talk : 15-20 minutes

Group Work: 20-25 minutes

Grammar Practice: 5-10 minutes

Closing Reminders: 5 minutes 


\section{Table 2}

ANALYSIS OF STUDENTS' TALK WITH THE FLORIDA TAXONOMY OF COGNITIVE BEHAVIOR (FTCB)

\begin{tabular}{|c|c|c|c|}
\hline Cognitive Level & Number of Responses & FTCB Description & $\%$ of Total Responses \\
\hline & & Knowledge of Specifics & \\
\hline 1 & 11 & Reads & 4.824561404 \\
\hline 3 & 15 & Identifies something by name & 6.578947368 \\
\hline 4 & 9 & Defines a meaning of a term & 3.947368421 \\
\hline 5 & 98 & Gives a specific fact & 42.98245614 \\
\hline \multirow[t]{3}{*}{6} & 3 & Tells about an event & 1.315789474 \\
\hline & & Total \%, Knowledge of Specifics & 59.64912281 \\
\hline & & Knowledge of Ways and Means of Dealing with Spec & ics \\
\hline \multirow[t]{3}{*}{11} & 1 & Cites Trend & 0.438596491 \\
\hline & & Total \%, Knowledge of Ways and Means & 0.438596491 \\
\hline & & Knowledge of Universals and Abstractions & \\
\hline \multirow[t]{3}{*}{14} & 3 & States generalized concept or idea & 1.315789474 \\
\hline & & Total \%, Knowledge of Universals and Abstactions & 1.315789474 \\
\hline & & Translation & \\
\hline 18 & 16 & Restates in own words or briefer terms & 7.01754386 \\
\hline 19 & 4 & Gives concrete example of abstract idea & 1.754385965 \\
\hline 20 & 1 & Verbalizes from graphic representation & 0.438596491 \\
\hline 22 & 2 & Translates figurative statements to literal statements or & vice versa 0.877192982 \\
\hline \multirow[t]{3}{*}{23} & 1 & Translates from language to English or vice versa & 0.438596491 \\
\hline & & Total \%, Translation & 10.52631579 \\
\hline & & Interpretation & \\
\hline 24 & 17 & Gives reason (tells why) & 7.456140351 \\
\hline 25 & 3 & Shows similiarities, differences & 1.315789474 \\
\hline 26 & 16 & Summarizes, concludes from observation of evidence & 7.01754386 \\
\hline \multirow[t]{3}{*}{27} & 3 & Shows cause and effect relationship & 1.315789474 \\
\hline & & Total \%, Interpretation & 17.10526316 \\
\hline & & Application & \\
\hline 30 & 9 & Applies previous learning to new situation & 3.947368421 \\
\hline \multirow[t]{3}{*}{31} & 4 & Applies principle to new situation & 1.754385965 \\
\hline & & Total \%, Application & 5.701754386 \\
\hline & & Analysis & \\
\hline 37 & 1 & Points out unstated assumption & 0.438596491 \\
\hline 42 & 2 & Detects error in thinking & 0.877192982 \\
\hline \multirow[t]{3}{*}{43} & 1 & Infers, proposes point of view, thoughts, feelings & 0.438596491 \\
\hline & & Total \%, Analysis & 1.754385965 \\
\hline & & Synthesis & \\
\hline \multirow[t]{3}{*}{47} & 1 & Produces a plan, proposes a set of options & 0.438596491 \\
\hline & & Total \%, Synthesis & 0.438596491 \\
\hline & & Evaluation & \\
\hline 54 & 3 & Evaluates something from evidence & 1.315789474 \\
\hline \multirow[t]{2}{*}{55} & 4 & Evaluates something from criteria & 1.754385965 \\
\hline & & Total \%, Evaluation & 3.070175439 \\
\hline
\end{tabular}


tional, teacher-guided, text-centered literature activities in foreign language classrooms.

Within sociocultural thought, language itself is absent of meaning. It is when language is placed into a social situation that signs and, hence, ideologies are internally created through external experience, which is mediated by and through tools. In an FL classroom, words can be defined or assigned their equivalents (casa $=$ house), but this falls short of language-learning goals. Language does not hinge upon memorizing vocabulary. Students may also take on the role of interpreters or reenforcers of meaning in the FL classroom. Meaning and signs in an FL classroom are socially introduced, reenforced, transformed, and modified through social speech.

It is necessary to identify the two functions of social speech that stem from and turn into dialogue and discourse. Vygotsky (1978) divided social speech into two areas. First, language arises initially as a means of communication between people and their environments. Second, language may be used as a tool to mediate the self as well as one's environment. Understanding that not all speech is designed for communicating with others is central to the notion of viewing discourse in the FL classroom, where more than one language is at play throughout the learning experiences of the instructor and class. Verbal communication between individuals or groups may take the form of utterance, dialogue, or discourse. Each of these has an effect on classroom talk; to fully understand the sociocultural framework, it is necessary to clarify these terms.

The root of communication, be it in a classroom or not, is the utterance. It is important to understand not only the purpose of utterances, but also their limitations in an FL classroom. Utterances exist within a context that reflects the nearest social situation. Utterances focus attention on communicative goals reached through dialogue, but sometimes the understanding of utterances overshadows dialogue in the FL classroom. As Bakhtin (1926/1981) notes, an utterance is not the completion of language or dialogue, but a continuation. An utterance's most important function in dialogue, and in the FL classroom, is one that teachers often forget: An utterance includes within it the possibility of responding to it, thus creating dialogue or discourse.

Given this understanding of utterance and dialogue, discourse is the next category of communication explained by the sociocultural framework. Bereiter's (1994) comments encompass the overall meaning and importance of discourse in an FLC:

(FL) classroom discussions may be thought of as part of the larger ongoing discourse. The fact that classroom discourse is unlikely to come up with ideas that advance the larger discourse in no way disqualifies it
... Dialogue, as a part of the FL classroom, is important, but should not be the goal of teachers or students because we incorporate much more into creating discourse that assists in learning a second language (p. 45).

Volosinov (1973) presents us with a more philosophical view of discourse, in which Well's (1999) concept of progressive discourse is easily identified:

Discourse (as with all signs generally) is interindividual. Discourse builds on understanding which has come to be over time and various situations with both the students and the teachers acting as speakers and listeners throughout communication. (p. 68)

Discourse extends beyond the dialogic level, which is based on utterances. Discourse is used to clarify ideas, establish concepts, react, and relate opinions to others.

As humans communicate through utterances, dialogues, discourse, and progressive discourse, we attempt to understand perspectives from the meanings generated through communication. Contexts and schemas in a textbased FLC are, obviously, brought about by means of language. We must not make the mistake of assuming that by understanding the language we also understand the speaker(s). Instructors should be aware of "passive understanding" of speech and communication in the classroom, because this kind of understanding can affect classroom discourse and, in turn, how or how much of the foreign language is learned. According to sociocultural thought, the processes mediated by signs and tools (eg, language learning) are dependent on opportunities to enter into dialogue and discourse.

\section{Methodology}

\section{Object of Study}

The classes that were observed, recorded, and transcribed were all part of Spanish 3201, a "bridge course" between language or linguistically focused courses and purely literature-based courses such as "The Latin-American Short Story" or "18th Century Spanish Drama." The university catalogue describes Spanish 3201 as having a strong conversational component. This analysis set out to understand what is meant by "conversation" (classroom talk) in a literature-based foreign language classroom such as Spanish 3201.

The class was observed for nine full weeks during the first half of the course. A total of 17 classes were observed during these nine weeks of instruction. The class was also observed two times during the last two weeks of the course (about 4 weeks after the last initial observation). The only difference noted in the classes observed during the last two 
weeks was that the students had prepared group presentations on various cultural topics.

The university in which the class is taught is on the semester system. There were no students who were native speakers of Spanish, although there were several that did have Hispanic heritage. In addition to the instructor, a total of 21 students ( 6 males and 15 females) gave the researcher permission to record, transcribe, and analyze their classroom talk.

The instructor - a native speaker of Spanish who holds a PhD in Hispanic Literature - had been teaching Spanish for 18 years and had taught the course three times before the study semester.

The seating arrangement for the class was traditional: five rows of four to six desks facing the front of the class. The instructor stayed in front of the class for the majority of the lessons observed and sometimes walked among the students while they were involved in group work.

Table 1 is an outline of the general activities that took place in this particular class. The table was constructed by the observer after listening to the data recorded, reviewing classroom observation notes, and interviewing three of the students as to the types and length of activities or segments in the Spanish 3201 class (Introduction to Hispanic Literature). Thes students interviewed constructed the procedural elements and agreed on the basic activities (General Announcements and Classroom Duties, Vocabulary and Prereading, Text-Centered Talk, Group Work, Grammar Practice, and Closing Reminders) and the order in which they took place. The only difference in the students' comments was about the amount of time spent in each activity (about five minutes' difference). Complete classes lasted from a minimum of 60 minutes to a maximum of 115 minutes.

\section{The Florida Taxonomy of Cognitive Behavior}

Discourse is one way that intellectual functioning is exhibited in college-level classrooms (Givens, 1976). To better understand the cognitive aspects of classroom discourse, The Florida Taxonomy of Cognitive Behavior (FTCB) (Givens, 1976) was applied to the data to distinguish and define the various levels of cognition observed in the classroom talk (see Appendix A for the complete FTCB). The FTCB is based on the work of Bloom (1956).

As Givens (1976) writes:

The taxonomy is sequentially arranged from the knowledge level to the evaluation level. The 'higher cognitive processes' and 'higher levels of thinking' (referred to) are the higher levels on the taxonomy chart and are presumed to involve more complex or abstract thought processes than the lower levels. (p. 13)
The FTCB was used to analyze the data at a cognitive level and assign the categories of utterance, dialogue, discourse, or progressive discourse to the talk that occurred in the classroom. For the purpose of this study, progressive discourse was understood as discourse that expanded or grew from previous discourse-level classroom talk. The FTCB is a way of objectively marking the most common cognitive levels (according to the FTCB) of classroom talk in the literature-based FLC.

According to Webb (1970), "the teacher's basic purpose is to guide students in the acquisition of knowledge and the development of intellectual skills" (p. 50). The FTCB can determine if, Givens (1976) states, "the central focus of the (classroom talk) is the acquisition of information or the utilization of cognitive processes in dealing with knowledge" (p. 50). Logically, the more the students and the teacher "deal with knowledge" and utilize higher cognitive processes as described by the FTCB, the more discourse should be evident in the class as defined by this study. The FTCB also helped to further define the oppor-

\section{Figure 1}

SITUATING TEXT-CENTERED

TALK IN CLASSROOM TALK

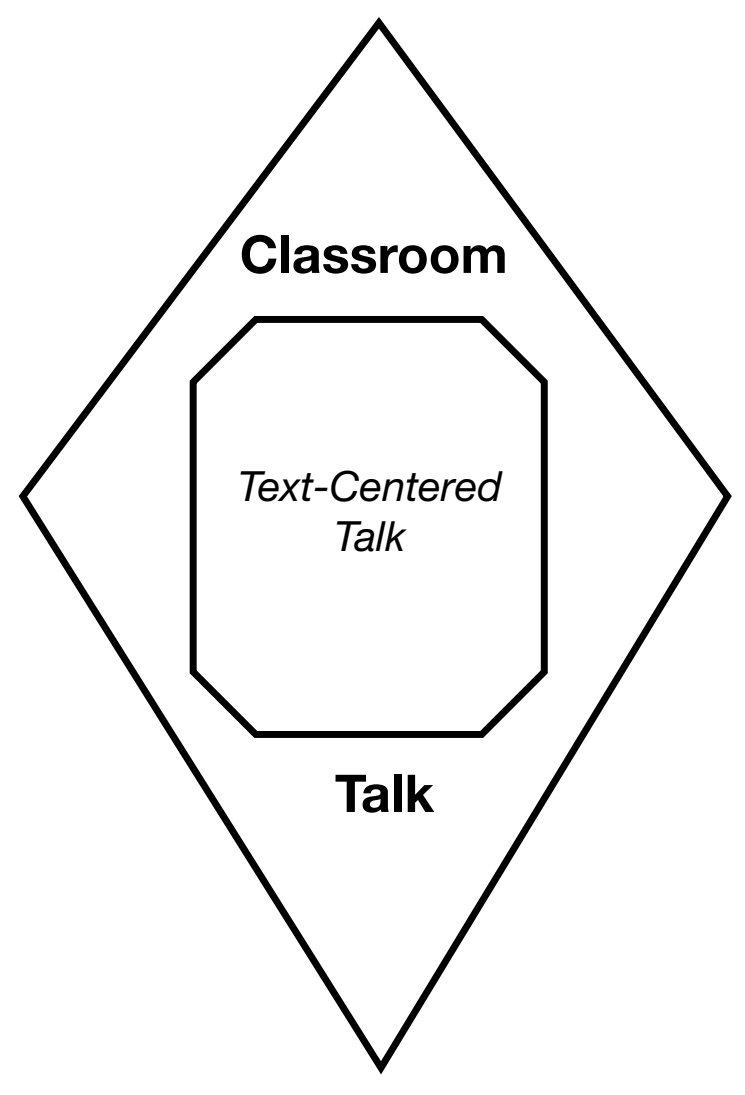




\section{Figure 2}

FIRST ANALYSIS OF TEXT-CENTERED-TALK

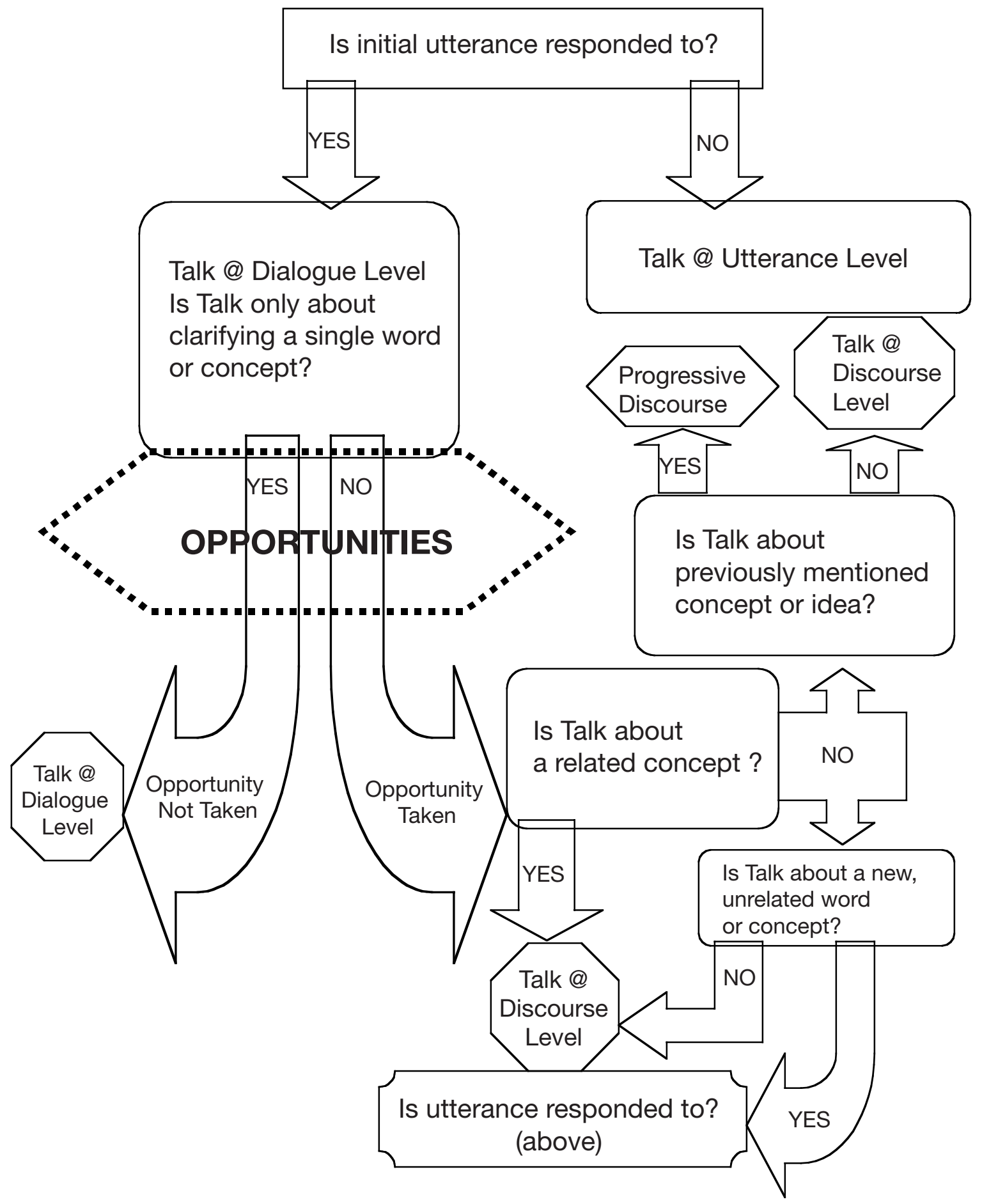


tunities provided (if any) to enter into extended classroom talk. An additional benefit of using this instrument was determining the level of cognitive behavior in a literaturebased FLC that should be reflected in the type of classroom talk recorded and analyzed.

According to Givens, there are seven increasingly complex levels of cognitive behavior, and there are 55 sublevels that fall under the main levels. These sublevels are not arranged hierarchically. The seven main levels of the FTCB, keeping with Bloom (1956), are:

1. Knowledge

2. Translation

3. Interpretation

4. Application

5. Analysis

6. Synthesis

7. Evaluation

\section{General Procedures}

In studies analyzing discourse, an important aspect of the methodology focuses on the specific topics that are transcribed and analyzed (Lyons, 1977; Keenan \& Schieffelin, 1976). To focus the analysis of this study, and in keeping with the methodology of the earlier work cited, the classroom talk that will be transcribed and analyzed will be Text-Centered Talk (TCT); that is, classroom talk that is explicitly about the text being read and studied.

The talk recorded in the FLC was reduced, transcribed, and analyzed according to the levels of classroom talk that are diagrammed in Figure 2: Utterance, Dialogue, Discourse, and Progressive Discourse. Moreover, the methodology allowed the researcher to investigate the role of opportunities (or lack thereof) provided by the instructor(s) or student(s) in the development of classroom talk.

Figure 1 illustrates the global focus of this study. Figure 2 illustrates the focus of the study at a microlevel and represents the first step in the process used to analyze the discourse - or the initial framework of analysis. Although the diagram may seem inflexible, it was useful in focusing the analysis.

The recorded data was not randomly assigned to the categories illustrated in Figure 2. The classroom talk was analyzed by two professionals in the field of SLA and Teacher Education, who mapped the classroom talk at a holistic level and a microlevel, as will be shown in the actual transcriptions. What is most important about Figure 2 is the role opportunities have in shaping classroom talk, which is part of what this study sought to investigate.

The classroom talk analyzed can be understood as emergent discourse, according to Brown and Yule's (1983) understanding that discourse grows steadily out of verbal and cognitive interaction. At this point, it is necessary to note distinctions between two common place terms in discourse analysis: coherence and cohesion.

Coherence is responsible for the development of communication (Schiffrin, 1994). This is not to say that cohesion (which is syntactically based as opposed to conceptually based) does not enter into building discourse, but within a sociocultural framework, coherence is understood as the driving force behind the emergence of discourse.

For example, a "coherent" discussion may be as follows:

A: Are you going to the movies today?

B: My car is still in the shop.

Speaker "A" understands that the implied answer is "No" because Speaker "B" does not have a car. In this example, the link between the utterances is purely conceptual.

\section{Figure 3}

DISTRIBUTION OF THE LEVELS OF TEXT-CENTERED CLASSROOM TALK
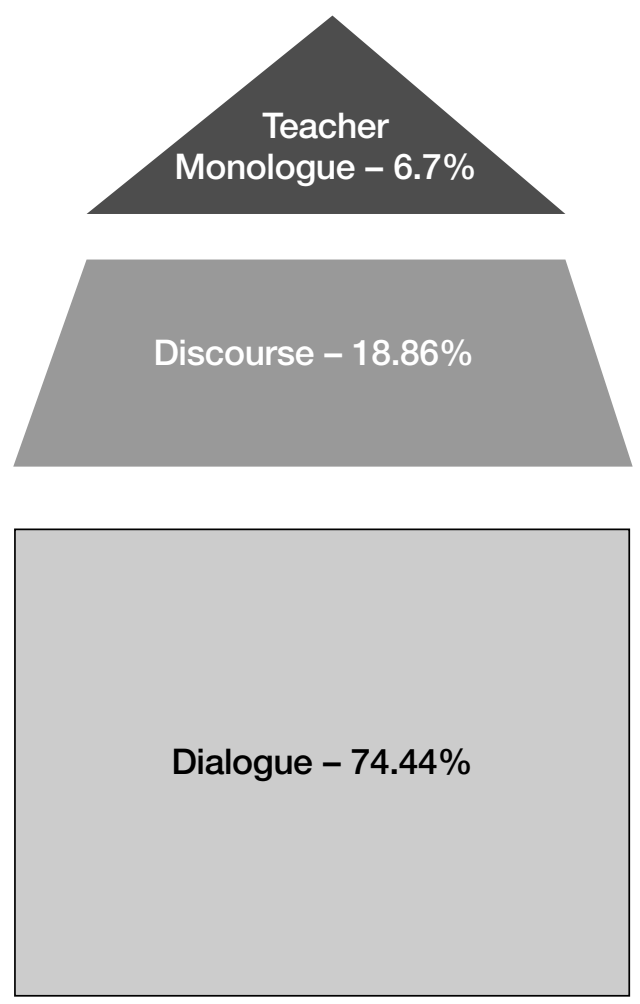
A discussion that can be understood as more cohesive may be as follows:

A: Are you going to the movies today?

B: No I am not going to the movies today.

There is a clear syntactic link between the utterances of Speaker A and Speaker B in the second example: The use of "going to the movies" by both speakers and the use of the verb "to be" in the present tense. There is but one concept in the second example, "going to the movies." Whereas, in the first example, there are two concepts: "going to the movies" and the reason for not being able to go to the movies (an inoperable car).

\section{Data Collection}

This study used the following guidelines for data collection:

1. The classroom talk recorded was from various "Whole Units" of instruction. Whole Units refers to complete instruction of the piece(s) of literature being studied, from introduction to completion, according to the syllabi provided by the instructor(s).

2. Each Whole Unit was reduced, transcribed, and coded according to the level of classroom talk: utterance, dialogue, and discourse. Examples are included in the later sections of the study.

3. The student responses during text-centered talk were coded and analyzed using the FTCB.

4. Teacher interviews were recorded but not transcribed completely. Relevant segments of the interviews were reduced and transcribed as needed.

\section{Transcription and Analysis}

The recorded classroom talk was reduced and transcribed; the symbols used throughout the data assisted the reader and the researcher in further analysis. The transcription conventions developed and used in conversation analysis by Brown and Yule (1983) were applied to the data.

After the data was reduced and transcribed, it was analyzed using:

1. Holistic Mapping using the concepts, opportunities, utterances, dialogue, discourse, and progressive discourse (as previously defined) to guide the analysis of classroom talk. This is generally outlined in Figure 1.

2. Givens' (1976) FTCB.

3. The transcribed data was then given to an outside observer to establish interrater reliability and trustworthiness after the observer was trained using the definitions of utterance, dialogue, and discourse (from above), and examples of each.

An underpinning of the sociocultural framework is that attention is paid to cognition and mind as products of individuals interacting and communicating. The methods of analysis mentioned above, although linguistically driven, are cognitively focused. By cross-referencing and comparing data analysis, what begins to emerge is a clearer picture of classroom talk and communication at a cognitive level through a sociocultural lens.

\section{Interobserver Agreement and Trustworthiness}

The present study will use Lincoln and Guba's (1985) four areas of inquiry for establishing the trustworthiness of a study. Lincoln and Guba (1985) addressed the concerns that focus on the reliability of the findings by focusing on questions for researchers.

To establish interobserver trustworthiness and agreement, this study made use of an external observer who was trained by the researcher prior to being permitted to view and analyze the data.

The observer was trained to analyze the data according to the three types of classroom talk defined earlier: utterance, dialogue, and discourse (including progressive discourse). The outside observer was also trained in how to analyze the data according to the FTCB.

Interobserver agreement was computed using the formula from Lincoln and Guba (1985):

Number of Agreements x 100

Number of Agreements + Number of Disagreements

An agreement between observers occured every time the element of analysis (type of classroom talk or FTCB) matched between observers. Interobserver agreement was calculated for type of classroom talk and the FTCB.

In the event that the outside observer and the researcher did not agree, they were to come to an understanding by referring to the given definitions and examples used during the observer training (which are presented later in this study).

It was understood that students in the course had successfully fulfilled the course requirements of the previous three semesters, which contributed to building their linguistic base and knowledge of the foreign language.

Students within this setting often have varied linguistic backgrounds in their chosen L2. They are now presented with an authority, the text, and only one interpreter, the teacher. In most cases, the students have graduated from reading and writing short texts to reading authentic literature and texts, a task that requires a new set of strategies from the teacher and students.

\section{Data Analysis}

Figure 3 illustrates the levels of classroom talk during textcentered-talk in the observed classes. There were a total of 84 exchanges, of varying lengths, between the instructor 
and the student(s). Of these exchanges, $18.86 \%$ were assigned the highest level of classroom talk: Discourse; $74.44 \%$ were assigned the Dialogue level of classroom talk. There were no instances of Utterance-level talk observed, but $6.7 \%$ of the exchanges were instances of Teacher Monologue.

Dialogue Example 1 is from an activity from the textbook that came after the assigned reading(s) and is labeled as $i$ Entendido? (Understood?) in the textbook. In these sections, the students were asked to evaluate statements as 'Cierto o Falso' (True or False) and asked to correct the false statements. The instructor always used this activity after the students read the homework passage. This activity was generally preceded by a Prereading or Vocabulary activity that was labeled 'Palabra por Palabra' (Word for Word) and 'Mejor Dicho' (Clearly Stated). In the following example, a clear teacher-centered Initiation-Response- Evaluation (IRE) pattern of communication is seen. The students have just read a selection about stereotypes.

Dialogue Example 1: Initiation-Response-Evaluation

( $\mathrm{T}=$ teacher, $\mathrm{S}=$ student, $\mathrm{Ss}=$ students $)$

1. T: Vamos a hacer rápidamente en la página $128 \mathrm{el}$ Cierto y Falso. Vamos a

2. hacerlos muy rápidamente.

3. Los norteamericanos no saben gozar de los placeres de la inactividad.

4. ¿Cierto o Falso? +

5. Ss: Cierto. $=$

6. T: OK. ¿Qué dice la lectura de los norteamericanos?

7. ¿Cómo se puede explicar eso?

8. ¿Cuál es, Cuál es según el autor el gran problema de los norteamericanos? +

9. Ss: Trabajan mucho. +

10. T: OK. Trabajan mucho, muy bien.

11. ¿Aquí qué pasa?

12. El ocio... ellos siempre tienen que hacer algo. Siempre quieren estar activos.

13. OK. Número dos: La televisión contribuye a formar y solidificar los

14. estereotipos. ¿Cierto o Falso? +

15. Ss: Cierto +

16. T: Los estereotipos son siempre ofensivos y se deben evitar. ¿Cierto o Falso? +

17. Ss: Cierto

18. T: Cierto.

19. Vamos a hablar de eso un momento.

20. ¿Por qué son malos esos estereotipos? Son divertidos, ¿no?

21. Pueden ser un cuento de chistes, no, para divertirse.

22. ¿Pero qué pasa con los estereotipos? +

23. S1: ¿Algunas personas creen que son verdad por todos?/

24. T: Sí. ¿Qué pasa?
25. Que son falsos, o sea que el grupo es tan diverso.

26. Es como los Estados Unidos. Hay gente que le gusta trabajar mucho pero

27. hay gente que no le gusta trabajar. O sea, hay de todo. O sea, lo mismo

28. sucede en America Latina, en España. Es bien difícil decir a todos

29. los mejicanos les gustan las fiestas.

30. OK. La pregunta número cuatro:

Taking a closer look at the above IRE example, we notice something even more interesting: The instructor has background-setting patterns within the answers or explanations to the questions, as in lines 10 to 12 and 16 to 21 . In lines 19 to 21 , the pattern is realized when the instructor answers her own questions. Again, lines 22 to 29 exemplify the classic IRE pattern of classroom talk. But, in lines 24 to 29 , we see another example of a background-setting pattern. This pattern of talk was the primary method that the instructor used to determine if the students had read and comprehended the selected read$\operatorname{ing}(\mathrm{s})$.

Dialogue-level classroom talk was also evident when the teacher began to ask questions about the topic of the reading, as in Dialogue Example 2 (below). In Dialogue Example 2, the students had read a selection about music and were beginning to talk about the reading. The entire talk that revolved around this reading was at the dialoguelevel.

\section{Dialogue Example 2}

1. T: Vamos a hablar un poquito de la música. A repasar un poco.

2. ¿Qué canciones hispanas conocen ustedes muy bien?

3. ¿Qué son muy populares. Sean españolas, latinoamericanas, en la America

4. Latina. (S1)? +

5. S1: Hmmm, ¿Ricky Martin? +

6. T: Sí, pero, ¿qué canciones de Ricky Martin? ++

7. S1: Uhmmmm ++

8. T: ¿El tiene alguna canción en Español?

9. S1: María $=$

10. $\mathrm{T}:=$ María. ¿Te gusta la canción de Ricky Martin? ¿Por qué?

11. S1: El ritmo es rápido. $=$

12. $\mathrm{T}:=$ El ritmo es rápido, muy bien. ¿De que trata la canción?

13. ¿De que es la canción? ++

14. S1: De una chica.

[Topic shift]

15. T: OK. Otra canción popular, (S2). ++

16. S2: Chiqui, Chiqui, Boom, Boom.

17. T: OK. Yo no podría decir ese título. 
18. ¿De que es esa canción? +

19. S2: De un amor por un hombre.

20. Es de lo que el hace sin ella con su corazón partida.

21. T: De un corazón partido.

22. ¿Y por qué te gusta la canción? +

23. S2: Tiene un ritmo muy rápido para bailar.

24. T: ¿Te gusta bailar? =

[Topic Shift]

25. ¿Otra canción hispana que le gusta? (S3)?

26. S3: La bamba=

27. $\mathrm{T}:=L a$ bamba, ite gusta? +

28. S3: Está bien. /

29. T: / Una canción hispana... buenísima, ¿no?

In this example, the talk did not later extend into the Discourse level. This type of dialogue was typical when the readings focused on global or cultural topics and not on specific stories or narratives, as in Dialogue Example 3 (below).

Dialogue Example 3 took place after the students had read a story about a Cuban immigrant's experiences when beginning a new life in the United States. This example is typical of the text-centered talk that took place when talking about the readings. It follows the IRE pattern as well, and more importantly, it creates opportunities for discourse that are not taken up by the instructor.

Dialogue Example 3 took place before the instructor led the class into the 'Entendido' section (see Dialogue Example 1).

\section{Dialogue Example 3}

1. T: OK. La lectura que nosotros tenemos para hoy es sobre... es de una

2. situación de un exiliado cubano. Vamos a ver. ++

3. ¿Quién es el autor de la lectura? ¿Alguién sabe? Quién es el autor? ¿Que hace

4. el autor?

5. Luis Fernández Caudi. Es periodista en Miami.

6. Y como ustedes saben hay varios periódicos en Miami, varios periódicos en

7. Español.

8. Ahora lo que es bien interesante es que es un relato autobiográfico, de su

9. propia vida.

10. ¿De que trata la lectura, de que trata? ¿Qué hace este personaje principal? +

11. S1: El obtiene un trabajo con / Coca-Cola.

12. T: / El obtiene un trabajo en la compañía Coca-Cola. OK.

[Topic Shift]

13. ¿En que momento se desaroya, en que tiempo se desarroya el relato?

14. ¿Cuando, que año, a que año se refiere la historia, (S2)?
15. ¿No sabes?

16. ¿(S3), a que año se refiere la historia?

17. S3: Un mil noventa y ...

18. T: Mil, Mil +

19. S3: / Nove..

20. T: / Novecientos ++

21. S3: isesenta y uno?

22. T: Muy bien. Mil novecientos sesenta y uno.

[Topic Shift]

23. Entonces, hace cuántos años de esa fecha fue la revolución cubana?

24. ¿Hace cuántos años de esa fecha? +

25. S4: ¿Dos / años?

26. T: / Dos años. ¿La revolución comenzó en mil novecientos, (S5)?

27. S5: cincuenta y nueve.

28. T: / Mil novecientos cincuenta y nueve. Bien, así que apenas hacia dos años.

29. O sea que él acababa de llegar a vela a Miami. OK.

[Topic Shift]

30. ¿Qué profesión tenía el protagonista en Cuba? +

31. S6: Era abogado. I

32. T: / El era abogado.

33. El era abogado, ¿y cómo era su vida en Cuba?

34. ¿Cómo era su vida?

35. ¿Cómo es la vida de un abogado? /

36. S6: / Comfortable +

37. T: La vida es cómoda. Muy bien.

[Topic Shift]

38. ¿Cómo viste?

39. Muy elegante, cuando la gente viste muy bien.

[Topic Shift]

40. Pero ahora hay un cambio.

41. ¿Por qué no puede ser abogado en la Florida?

42. ¿Alguien sabe?

43. ¿Conocen las reglas? (S7)? No? ++

44. S8: ¿Hay que tener licencia? /

45. T: / Sí, obviamente para ser abogado, ser médico, hay que tener licencia. Hay

46. que pasar los exámenes. El famoso Florida Bar.

[Topic Shift]

47. De hecho, esto es muy interesante porque muchos inmigrantes vuelven a la

48. escuela graduada, la escuela profesional, para sacar la licencia de la

49. profesión. ¿Pero qué pasó con este señor, con el protagonista?

50. No podía ser abogado.

51. Hay que tener permiso, una persona que, obviamente el no era ciudadano,

52. ¿hay que ser ciudadano para trabajar en los Estados Unidos?

53. (S9), ¿por qué? 
[Topic Shift]

54. ¿Qué hay que tener? I

55. S9: / Visa para trabajar./

56. T: / Hay que tener una visa para trabajar, exactamente.

57. No hay que ser ciudadano. OK.

58. Vamos a hacer rapidamente las preguntas de "entendido," rapidamente.

Clearly, the IRE sequence is seen in this example. There are examples of instructionally embedded IRE in lines 1 to 12 and 37 to 52; the embedded IRE patterns are evident in lines 3 to 9,38 to 40 , and 49 to 51 .

This type of classroom talk mainly addresses known answer-type questions, in which specific facts from the text are used as a point of reference and a means of evaluating text comprehension for the instructor.

\section{Discourse}

The text-centered talk extended into the Discourse level $18.86 \%$ of the time that the classes were observed. The following example of discourse took place after the instructor had introduced and defined, with help from the students, the idea of 'estereotipo' (stereotype).

\section{Discourse Example 1}

1. T: Vamos a volver a la cuestión de los estereotipos. Son ideas que se tienen.

2. Ahora. ¿Qué tipos de ideas son?

3. ¿Son ideas profundas o son ideas / simples?

4. S3: / Simples

[Topic Shift]

5. T: ¿Por qué? Cuál es un estereotipo? +

6. S3: Las rubias son muy divertidas. +

7. T: OK. Muy bien. Eso es un estereotipo.

[Topic Shift]

8. ¿Cuál sería un prejuicio? ++

9. S3: No me gustan las rubias / porque...

10. T: / Es algo que crees de verdad.

11. Por ejemplo, las mujeres hispanas no pueden manejar.

12. OK. ¿Cuales son unos prejuicios en la universidad?

[Topic Shift]

13. S4: Los atléticos. /

14. T: / Los atletas. ¿Qué pasa con los atletas? +

15. S5: Bobos. /

16. T: / Son bobos. ¿Y eso es cierto?

17. ¿Por qué es un estereotipo? ¿Por qué es un estereotipo? $++$

18. S6: Porque (athlete) tiene un "four point o." ++

19. T: Hay atletas muy inteligentes. OK.

20. OK, otro estereotipo aquí en (la universidad). O en una universidad. ++

[Topic Shift]

21. S7: Todos los estudiantes son borrachos.
22. T: Sí. Eso es cierto. Que los estudiantes son unos borrachones. No es que

23. están sino que son, eso es muy fuerte.

[Topic Shift]

24. Otro estereotipo, ¿con el dinero?

25. Qué los estudiantes no tienen dinero. Y algunos sí tienen. Tienen mejor

26. coche, mejor carro del que yo tengo.

[Topic Shift]

27. Vamos a pensar un poco en lo que define un estereotipo.

28. ¿Qué define un estereotipo?

29. La cultura. el grupo social, /

30. S8: / La historia.

31. T: OK vamos a pensar.

[Topic Shift]

32. ¿Cuáles son los objetos o los subjetos de estereotipos? ++

33. S9: ¿Extranjeros? +

34. T: Extranjeros, muy bien.

35. Algo que uno no conoce.

36. ¿Qué más? +

37. S10: Raza.

38. T: La raza. Tiene que ver con lo que uno es. +

39. S11: La religión. +

40. T: La religión. Muy bien. Religión, Raza. +

41. S12: Dinero. +

42. T: Muy bien, la clase social.

43. Las personas de lugares específicos.

We can see how the students took advantage of the idea of stereotypes by first talking about a real-life example in lines 5 to 26. Also, within these lines, the students distinguish stereotypes from prejudice. The example ends with the instructor and students naming causes for stereotypes and prejudices (lines 28 to 40 ). It is interesting to note that even though students gave one- or two-word answers, the instructor extended them to pose more questions and opportunities for the classroom talk to develop into discourse, as seen in lines 5, 11 to 12,16 to $17,20,28$, 32 , and 36.

Another example of discourse (lines 1 to 8 ) includes an example of Teacher Monologue (TM). The TM only served to introduce the beginning of text-centered talk and not to clarify the meaning of 'refranes' (sayings). However, despite the TM, this classroom talk does extend into discourse.

\section{Discourse Example 2}

1. T: OK. Nosotros hoy vamos a hablar un poco de los refranes.

2. Los refranes son bien importantes en todas las culturas, ¿no?

3. Pero especialmente en español, creo, somos muy refraneros. 
4. sea usamos mucho, mucho, los refranes. En Puerto Rico tenemos muchos

5. refranes. Muchos heredados de la cultura española.

6. Bueno ustedes saben que también en la cultura hispánica hay muchos

7. piropos. Esto es otra cosa que están por allí dentro de la misma familia de los

8. refranes. ¿Alguién me puede decir lo que es un refrán?

9. ¿Qué es un refrán, (S1)? ++

[Topic Shift]

10. S1: No leí /

11. $\mathrm{T}$ : / ¿No leíste?

12. OK. Alguién que haya leído. ++

[Topic Shift]

13. S2: ¿Sayings? +

[Topic Shift]

14. T: OK. En Español. +

15. S2: ¿En Español? /

16. T: / Si, es parte del vocabulario.

17. ¿Cómo pueden definir un refrán? Si. +

18. S3: Frases hechas que no cambian con el uso. ++

19. T: OK. Si. Formas de decir. Una expresión idiomática.

[Topic Shift]

20. ¿Cuales son algunos refranes populares?

21. En los Estados Unidos, en el inglés hay mucho refrán. ¿Cuáles son algunos

22. refranes populares, ahora? ¿Expresiones populares?

23. Bueno, expresiones no son necesariamente refranes, ¿pero cuales son unas

24. expresiones populares?

[Topic Shift]

25. Una expresión que yo no entendería. Ustedes saben yo soy de otra cultura.

26. Mis expresiones son como "Qué chevere," cosas así.

[Topic Shift]

27. ¿Qué dicen ustedes hoy en día? ++

28. S4: Cool /

29. T: / ¿Qué cool? Vamos a ver. Tienen que usar unas expresiones. ¿No saben?

30. Cuales son unas expresiones que usan hoy en día.

[Topic Shift]

31. S5: ¿Quieres expresiones o 'sayings'? ++

32. T: Expresiones o refranes. /

33. S6: / OK

34. T: ¿Cómo cual? ++

[Topic Shift]

35. S6: Absence makes the heart grow fonder? /

36. T: / What? +

37. S6: Absence makes the heart grow fonder. /

38. T: / ¿Qué significa eso en español?

39. ¿Cómo pueden traducir una expresión como esa? ++ 40. S7: You can't.

41. T: / ¿Cómo, (S7)? ¿Cuál es la primera palabra? La ausencia... /

42. S8: / ¿Hace el corazón más fuerte? +

43. T: O sea, con la ausencia uno se da cuenta de lo que tiene.

44. No sé si será eso exactamente, pero.

[Topic Shift]

45. Yo quiero que ustedes con la persona que esté al lado hagan uno y dos de

46. "Alto."

In the above example, the instructor asks the students for examples of 'refranes' instead of providing more of her own. This helps the students extend their communication beyond the dialogue level. Interestingly, the discourse ends rather abruptly at a point when the students are just beginning to use Spanish in new ways (in lines 40 to 46). In this instance, after reaching the discourse level of communication, the instructor did not offer opportunities to extend the discourse even further.

Discourse Example 3 (below) is particularly interesting because it shows how the classroom talk changes once the instructor relates to the students' own experiences in trying to understand the reading. This reading was about the colorful festivals and ceremonies of Mexico. The author, Octavio Paz, wrote about the visual and cultural elements one encounters when travelling through Mexico. After talking about what a 'fiesta' (party) entails in Mexico, the instructor asked the students to talk about ceremonies, and especially one that had recently taken place on campus. This led the class into talking about the upcoming holidays.

\section{Discourse Example 3}

1. T: ¿Ceremónia? Ayer tuvimos una ceremonia en (la universidad). ¿Qué es una

2. ceremonia, (S5)? ++

3. S5: Un grupo de personas que están en un lugar. I

4. T: / OK. Muy bien. O un grupo de personas que están en un lugar para

5. celebrar.

6. ¿Y es una celebración formal o informal? /

7. S5: / Formal /

[Topic Shift]

8. T: / ¿Formal, no? ¿Qué celebrábamos ayer en (la universidad)? ++

9. S6: ¿El cumpleaños de la unversidad? +

10. T: Cuantos años? 150 años, fue increíble. Asistieron, me imagino.

[Topic Shift]

11. ¿Qué cosas vieron en la fiesta de ayer? ¿Qué cosas vieron en la ceremonia? ++

12. S7: Comida.

13. T: Había comida. Había baile, danza? No. 
14. ¿Qué había de las cosas que vemos aquí, colores, danzas, fuegos artificios, trajes, frutos.

[Topic Shift]

15. ¿Qué había en esta ceremonia? +

16. S8: Años y años de trajes. /

17. T: / Ah, los trajes antiguos.

18. ¿Qué más había en la ceremonia? +

19. S9: Canciones. /

20. T: / Habian canciones, muy bien. Habian canciones. ¿Qué otra cosa había? +

21. S10: Fuegos / de...

22. $\mathrm{T}$ : / Si, fuegos de artificio. A mi me sorprendió que tuvieran fuegos de artificio.

23. ¿Qué más tuvimos ayer en la ceremonia de celebración? Tuvimos trajes

24. antiguos. Tuvimos fuegos artificiales. ++

[Topic Shift]

25. S11: En el nuevo año. ++

26. T: ¿Cómo? ++

27. S1l: ¿Nuevo / año?

[Topic Shift]

28. T: / No, pero ayer, ayer, ayer.

29. Canciones, comida. No sé si habían dulces pero si había comida gratis, ¿no?

30. Eso es decir que en (la universidad) hacemos fiestas también, ¿no? Y los

31. estudiantes como ustedes, también, muchas fiestas.

[Topic Shift]

32. ¿Y que hacen los estudiantes en las fiestas?

33. Vamos a ver. ¿Qué hacen en las fiestas? +

34. S12: Beben /

35. T: / Beben, otra palabra para beber. Beben mucho, ¿que hacen? /

36. Ss: / Emborracharse. +

37. T: Muy bien, se emborrachan. La palabra de vocabulario muy importante. Se

38. emborrachan.

39. ¿Cuál es la bebida favorita de los estudiantes? +

40. S13: La cerveza. /

41. T: / Cerveza. ¿Y toman cerveza mejicana? Muy popular. / Dos equis.

42. S14: / Corona.

43. T: Corona, muy bien.

[Topic Shift]

44. ¿Qué fiestas hay en los Estados Unidos? ¿Que ustedes celebran? Hay una celebración? +

45. S15: Madri Gras. ++

[Topic Shift]

46. T: No, en febrero. Estaba pensando en fiestas / grandes.

47. S16: / El día de San Valentín. +

48. T: ¿Otro nombre para el día? ++

49. S17: El día del amor.

50. T: Bueno, muy cerca. El día de los enamorados, el día de los enamorados.

51. ¿Y a quien le gusta el día de enamorados? ¿A todo el mundo, no?

[Topic Shift]

52. ¿Qué hacen ustedes el día de los enamorados? ¿Qué haces el día de los

53. enamorados? ¿Vas a dormir, no? ++

54. S18: Normalmente, yo trabajo. +

55. T: Ohhhh, eso es un día aburrido. ¿Alguien hace algo? ¿Nadie?

56. S13: Estar borracho. ++

57. T: ¿Bueno es que sois todos solteros en la clase o que? ++

58. S14: Me emborracho. ++

59. T: Qué aburrido. ¿Normalmente que hace una persona que está enamorada? ++

60. S15: Gastar dinero. I

61. T: / Como gastar dinero. +

62. S16: Dulces. $/$

63. T: / Regalar dulces, OK, que más? ++

64. S16: Va a la cena. I

65. T: / Uno va al restaurante a cenar con le novio, amigo, esposo, esposa.

[Topic Shift]

66. Ahora, ¿ustedes creen que hay fiestas revueltas en los Estados Unidos?

67. Vamos a usar esa comparación.

68. ¿Hay fiestas revueltas? ¿Son las fiestas en la universidad tan revueltas como

69. en la universidad en México? Revueltas (writes on board). Una palabra que usa Octavio Paz.

[Topic Shift]

70. ¿Qué significa revueltas? ++

71. S17: ¿Fiestas? /

72. T: / Sí, fiestas muy locas. ¿Son las fiestas revueltas de (la universidad)? /

73. S17: / Sí. +

[Topic Shift]

74. T: Depende de la fraternidad, ¿no? Bueno, vamos a hacer en la página 41 ,

75. en grupos.

Once again, the discourse suddenly stops; in this case after an attempt is made to define 'revueltas' in lines 66 to 75 and the students move into groups. It is very important to note that all the classroom talk that extended into discourse took place when the authentic reading was more cultural in substance than academic. In other words, classroom talk was more likely to extend into discourse when students did not have to interpret the meaning of "Literature" and relied on their own experiences and expertise to talk about a cultural topic. There were no instances of discourse that revolved around "Literature" (short stories, poems, essays, and the like). 
From these observations and analysis, it is clear that students felt more comfortable extending the classroom talk when they were the ones who were the experts, not the instructor. The instructor was able to provide opportunities for this to happen and did listen and extend the student's responses, as in lines 58 to 65 .

There was no student-initiated talk that assisted in building or extending the discourse in the classes observed. This is not to say that the students did not take part in the classroom discourse. However, the students did not initiate (e.g., ask questions, ask for clarification, or make a new interpretation) discourse. They only responded to questions or statements made by the instructor that assisted the development of discourse. This is not understood as student-initiated, but as student-supported discourse, as seen in Discourse Example 1. Students did not usually speak unless called upon by the instructor. This pattern placed the responsibility of initiating discourse on the instructor and placed students in a supporting role.

Also, during the moments of text-centered talk in the observed classes, the students did not speak to each other in Spanish or English. The instructor acted as a filter for the statements and answers of the students gave. If the instructor accepted the statement or answer, then she would try to extend it by asking another student to give their opinion or answer. The main patterns of initiated communication (where dialogue or discourse begins) were from teacher to student to teacher to a different student, or teacher to student to same student to teacher to different student.

The readings in this course are treated as "having intrinsic meaning." This is better understood by looking at Table 2, which shows the cognitive level of the student's spoken responses to the instructor's questions about the authentic readings or texts that were used during the classes. The overwhelming majority of student responses (almost 60\%) were those that dealt with knowledge of specifics (main character, where the story takes place, author, true or false statements, and the like). The percentage of students responses at the Knowledge of Specifics level was $59.65 \%$, and within this category, $42.98 \%$ of the student responses included a specific fact that could be found in the text. The following example is from a reading about the role of bars in the social life of Spain and other Spanish-speaking countries.

\section{Knowledge of Specifics Example}

1. T: Vamos a pensar en... no vamos a pensar en la bebida. Hay todo un

2. aspecto social que se da en los bares. ++

3. S15: Se puede comer en los bares./

4. T: / Exactamente. Uno sale del trabajo y uno tiene hambre. Va a comer.
5. Vamos a pensar en la condición social. +

6. S16: Para enontrarse con los amigos.+

7. T: Sí. Encontrarse con los amigos. Muy bien. habíamos dicho antes, para

8. hacer nuevos amigos.

9. Y hay una cuestión que tiene que ver obviamente con el mundo de los

10. negocios y el mundo profesional.

11. ¿Para qué va la gente a los bares? ¿Señor? ++

12. S14: Para hablar de los negocios. +

13. T: Cerrar tratos. ¿Qué hacen los hombres de negocios en los Estados Unidos?

14. Van al campo de golf. Hay más negocios en el campo de golf que... bueno

15. hay muchos negocios. Y lo mismo sucede en los bares en España.

16. La próxima pregunta. ¿Unos van todas las mañanas a tomar un café en

17. donde? ¿En donde se toma el autor un café? +

18. S15: En los bares.

The responses given by the students in lines 3, 6, 12, and 18 are all very specific answers that came from the text that was read for homework the night before. More importantly, the students are not applying their own knowledge or previous knowledge, not analyzing the reading for various points of view (eg, the effect the custom had on the bar owner's livelihood), not synthesizing the information given (e.g., talking about what might be the "average day" for a Spaniard), not evaluating this social habit (does it affect family relations or are only men allowed to go to the bars and interact like the author?).

Missed opportunities to build discourse from classroom talk, as in the Knowledge of Specifics Example, are always present when the text is treated as only having intrinsic meaning and not used in a way that assists the development of language and cognitive skills. In this example, the cognitive level of the classroom talk reflects the text that was read, but the talk gives students little room to think and speak.

\section{Trustworthiness and Reliability}

The data for the present study was analyzed and discussed by two trained observers before arriving at the final results.

In accordance with Lincoln and Guba's standards of trustworthiness and reliability (Truth Value, Applicability, Consistency, and Neutrality), high levels of agreement were reached by training the observers with data from a pilot study that used the same framework and methodology. The final computed interobserver agreement averages are:

- Interobserver agreement for the level of classroom talk, $93.33 \%$. 
- Interobserver agreement for the FTCB levels, 91.23\%.

- The final average interobserver agreement (including Level of Classroom Talk and FTCB Levels), 92.38\%.

\section{Conclusions}

The findings are briefly stated below:

- Most (74.44\%) of the text-centered classroom talk in the course observed was Dialogue.

- Text-centered talk extended into Discourse $18.86 \%$ of the time during the course observed.

- The instructor did offer opportunities for dialogue to extend into discourse. However, there was no studentinitiated dialogue that extended into discourse.

- The readings in this course were treated as having intrinsic meaning. This had a direct affect on the level of talk in the classroom, inasmuch as the classroom talk was mostly at the Dialogue level. This is seen in the FTCB analysis, where the students' cognitive behavior centered around knowledge of specifics (59.65\%).

If we think that "meaningful practice" in an FLC is based in authentic readings and texts, then what comes to mind is a classroom that evolves and revolves around the plans of the instructor. If these plans are to succeed in extending classroom talk beyond the dialogue level, then there must be opportunities for exploratory talk, coconstruction of meaning, and scaffolding, as defined earlier in the study.

This type of meaningful practice would also include the students engaging in active mental participation and developing their cognitive abilities in the second language. As Anton (1999) states, "cognitive development originates in social context" (p. 83) when teachers promote active mental participation. The data analysis has shown that the cognitive development promoted in this class was mostly that of answering specific questions, which mostly took place at the Dialogue level of talk.

Interestingly, the few examples of higher mental functions (Vygotsky, 1978) took place at the level of Discourse during classroom talk. The FTCB has reflected Bloom's (1956) beliefs that active mental participation in a social context may lead to the use of higher cognitive skills. It follows that classroom talk that extends itself into the level of discourse or exploratory talk (Wells, 1999) may also promote the use of language and the development of more linguistic tools, which promote and support higher cognitive functions and skills in the FLC.

The use of texts in the FLC is nothing new. But if we are to truly engage the students in meaningful practice, then the norms of communication that envelope the textcentered talk in a FLC such as Spanish 3201 have to be reconsidered. The norms set out by the instructor ulti- mately affect the discourse practices of the classroom community (Forman, 1995). The observed discourse practices in the present course are based much more on the cohesion of classroom talk than on the coherence of the same as defined previously. Classroom talk that is cohesive is understandable inasmuch as the questions asked already have answers, and students have to understand the text in order to participate. Classroom talk that is coherent uses the text to build discourse and communication around ideas that come from students and teachers understanding each other.

Finally, this study touches on the issue of the stated vs. the enacted curriculum (Smithson, 1995, Tobin, 1997). Obviously, the stated curriculum is what students are told the class is going to encompass and what they are expected to learn from the course. The enacted curriculum is the reality of the day-to-day unfolding of the patterns of interaction and norms of communication in the classroom environment. Hopefully, the stated and enacted goals and objectives of any given course are, within reason, identical. However, whenever we encounter two vastly different curricula, we must then begin to ask questions so that our purpose as educators does not become just words on paper, but instead ideas and thoughts from our students.

\section{Instructional Implications}

An important instructional implication of this study is that we are better able to understand what instructors believe to be is the actual purpose of using authentic texts and readings in the teaching of a foreign language. These beliefs, according to the instructor observed, are based on superficial readings for specific information in the hopes of building a vocabulary base that will assist in building oral proficiency. However, if one is to take this perspective, then we must also offer opportunities for the students to engage in what Wells (1999) called the practice of education, as outlined below:

- The activities undertaken are such that, although chosen by the teacher for their cumulative contribution to an understanding of the central theme, they allow for groups of students to make them their own and progressively to exercise more choice over how they are conducted.

- They involve a combination of action and reflection, and of group work, individual reading and writing, and whole-class discussion.

- Goals are made explicit and the relationship between these goals and the means by which they are to be achieved is made the subject of discussion.

- Perhaps most important, there are frequent opportunities for students to express their beliefs and opinions, to calibrate them with those of their peers, and to 
change them in the light of persuasive argument or further information.

The above guidelines are central to producing not only a productive learning environment, but also form the foundation of the modern foreign language classroom, in which cognition and thinking are just as important - if not more so - than the language being used in build understanding, knowledge, and, in the long run, proficiency.

\section{References}

Aljaafreh, A. \& Lantolf, J.P. (1994). Negative feedback as regulation and second language learning in the Zone of Proximal Development. The Modern Language Journal, 78, 465-83.

Allwright, D. (1984). The importance of interaction in classroom language learning. Applied Linguistics, 5, 165-71.

Akyel, A. \& Yalcin, E. (1990). Literature in the EFL class: A study of goal-achievement incongruence. ELT Journal, 44,3, 174-80.

Anton, M. (1999). The discourse of a learner-centered classroom: Sociocultural perspectives on teacher-learner interaction in the second language classroom. The Modern Language Journal, 83, 303-18.

Bakhtin, M. M. (1981). The dialogic imagination: Four essays by M. M. Bakhtin, Ed. M. Holquist. Austin: University of Texas Press.

Bakhtin, M. M. (1984). Problems of Dostoevsky's Poetics. Minneapolis: University of Minneapolis Press.

Bakhtin, M. M. (1986). Speech Genres and Other Late Essays. Austin: Universtity of Texas Press.

Barnes, K. G. (2000). Revising a Spanish novel class in light of standards for foreign language learning. ADFL Bulletin, 31,2, 44-48.

Bateson, G. (1972). Steps to an Ecology of Mind. New York: Ballentine.

Bereiter, C. (1994). Implications of postmedernism for science or science as progressive discourse. Educational Psychologist, $29,1,3-12$.

Bernhardt, E. B. (1995). Teaching literature or teaching Students? ADFL Bulletin, 26, 2, 5-6.

Blackbourn, B. (1986). The transition from language courses to literature: A pragmatic stance. The French Review, 60,2, 196-202.

Bloom, B. S (1956). Taxonomy of Educational Objectives: Handbook I, Cognitive Domain. New York: McKay.

Bretz, M.L. \& Persin, M. (1987). A working model for the teaching of literature at the introductory level. The Modern Language Journal, 71, 165-70.

Brooks, F. B. et al (1997). When are they going to say 'it' right?
Understanding learner talk during pair-work activity. Foreign Language Annals, 30,4, 524-40.

Brooks, F. B. \& Donato, R. (1994). Vygostkian approaches to understanding foreign language learner discourse during communicative tasks. Hispania, 77, 262-73.

Brown, G. (1996). Language learning, competence and performance. In: Performance and Competence in Second Language Acquisition (pp. 187-203). Cambridge University Press.

Brown, G. \& Yule, G. (1983). Discourse analysis. Cambridge University Press.

Carrasco, R. L. (1981). Expanding awareness of student performance: A case study in applied ethnographic monitoring in a bilingual classroom. In H. T. Trueba, G. P. Guthrie, \& K. H. $\mathrm{Au}$ (Eds.), Culture and the Bilingual Classroom: Studies in Classroom Ethnography (pp.153-177). Rowley, MA: Newbury House.

Carter, R., \& Long, M. (1990). Teaching literature in EFL classes: Tradition and innovation. ELT Journal, 44,3, 215-21.

Cazden, C. (1986) Classroom discourse. In M.C. Wittrock (Ed.), Handbook of Research on Teaching (pp. 432-63). New York: Macmillan.

Chamot, A. U. (1994). A model for learning strategies instruction in the foreign language classroom. Georgetown University Round Table on Languages and Linguistics 1994. Georgetown: Georgetown Press.

Coulthard, M.C. (1977). An Introduction to Discourse Analysis. London: Longman.

Davidheiser, J. (1977). An interdisciplinary approach to the teaching of foreign literature. The Modern Language Journal, 61, 25-31.

Davis, J. N., et al. (1992). Readers and foreign Languages: A survey of undergraduate attitudes toward the study of literature. The Modern Language Journal, 76, 320-31.

Davis, J. N. (1992). Reading literature in the foreign language: The comprehension/response connection. The French Review, 63,3, 359-70.

Davis, J. N. (1989). The act of reading in the foreign language: Pedagogical implications of Iser's teader-Response Theory. The Modern Language Journal, 73, 420-28.

Deyes, A.F. (1974). Speech activity in the language class. ELTJ, 28, 222-226.

Donato, R. (1994). Collective Scaffolding in Second Language Learning. In Lantolf and Appel, Eds., Vygotskian Approaches to Second Language Research. Norwood, NJ: Ablex, 33-56.

Donato, R. \& Adair-Hauk, B. (1992). Discourse perspectives on formal instruction. Language Awareness, 1,2, 73-89.

Dunn, W. E. \& Lantolf, J. P. (1998). Vygotsky's Zone of Proximal Development and Krashen's i + 1: Incommensurable constructs; Incommensurable theories. Language Learning, 48, $3,411-42$. 
Elliot, R. (1990). Encouraging reader-response to literature in the ESL Situation. ELT Juornal, 44,3, 191-98.

Engestrom, Y. (1991). Activity theory and individual and social transformation. Activity Theory, 7/8, 6-17.

Fillmore, L. W. (1982). Instructional language as linguistic input: Second language learning in classrooms. In L.C. Wilkinson (Ed.), Communicating in the Classroom ( $p p$. 283-96). New York: Academic Press.

Forman, E. A. \& Cazden, C.B. (1985). Exploring Vygotskian perspectives in education: The cognitive value of peer interaction. In J. V. Wertsch (Ed.), Culture, Communication and Cognition: Vygotskian Perspectives (pp.332-47). New York: Cambridge University Press.

Floriani, A. (1994). Negotiating what counts: Roles and relationships, texts and contexts, content and meaning. Linguistics and Education, 5, 241-74.

Frye, N. (1984). Literary and linguistic scholarship in a postliterate world. PMLA, 99, 990-95.

Gass, S. \& Varonis, E. M. (1994). Input, interaction, and Second Language Production. SSLA, 16, 283-302.

Geertz, C. (1973). The interpretation of cultures: Selected essays by Clifford Geertz. New York: Basic Books.

Givens, C. F. (1976). A descriptive study of the cognitive level of classroom discourse of college professors and students. Unpublished dissertation. Claremont Graduate University. Claremont, CA.

Graden, E. C. (1996). How language teacher's beliefs about reading instruction are mediated by their beliefs about students. Foreign Language Annals, 29,3, 387-95.

Hall, J. K. (1999). The communication standards. In J. Phillips and R. Terry (Eds.), Foreign Language Standards: Linking Research, Theories, and Practices (pp. 15-56). New York: NTC.

Hall, J. K. (1997). A consideration of SLA as a theory of practice: A response to Firth and Wagner. The Modern Language Journal, 81, 301-6.

Hall, J. K. (1995). (Re)creating our world with words: A sociohistorical perspective of face-to-face interaction. Applied Linguistics, 16,2, 206-32.

Hall, J. K. (1995). “Aw, man, where you goin'?": Classroom interaction and the development of L2 interactional competence. Issues in Applied Linguistics, 6,2, 37-62.

Halliday, M. A. K. (1993). Towards a language-based theory of learning. Linguistics and Education, 5, 93-116.

Halliday, M. A. K. (1978). Language as social semiotic: The social interpretation of language and meaning. London: Arnold Press.

Halliday, M. A. K. ( 1975). Learning how to mean. London: Arnold Press.
Hankins, O. (1972). Literary analysis at the intermediate level. The Modern Language Journal, 55,5, 291-95.

Harper, S. (1988). Strategies for teaching literature at the undergraduate level. The Modern Language Journal, 72,iv, 402-8.

Hester, R. (1972). From reading to the reading of literature The Modern Language Journal, 55,5, 284-90..

Isenberg, N. (1990). Literary competence: The EFL reader and the role of the teacher. ELT Journal, 44,3, 181-90.

Iser, W. (1978). The act of reading: A theory of aesthetic response Baltimore: Johns Hopkins University Press.

Keenan, E., \& Scheiffelen, B. (1976). Topic as discourse in notion. In C. Li \& S. Thompson (Eds.): Subject and Topic. New York: Academic Press.

Kempf, F. R. (1995). The dialectic of education: Foreign language, culture, and literature. ADFL Bulletin, 27,1, 38-46.

Knutson, E. (1993). Teaching whole texts: Literature and foreign language reading instruction. The French Review, 67,1, $12-27$.

Kramsch, C. (1985). Literary texts in the classroom: A discourse model. The Modern Language Journal, 69, 356-66.

Kumaravadivelu, B. (1999). Critical classroom discourse Analysis. TESOL Quarterly, 33,3, 453-84.

Kumaravadivelu, B. (1993). Maximizing learning potential in the communicative classroom. The Modern Language Journal, 76,i, 41-49.

Lantolf, J. P. (2000). Sociocultural Theory and Second Language Learning. Oxford, U.K.: Oxford University Press.

Lantolf, J. P. \& Appel, G. (1996). Vygotskian Approaches to Second Language Research. Norwood, NJ: Ablex Publishing.

Lave, J. \& Wegener, E. (1991) Situated learning: Legitimate peripheral participation. Cambridge University Press.

Lave, J. (1977). Tailor-made experiments and evaluating the lntellectual consequences of apprenticeship training. Quarterly Newsletter of the Laboratory of Comparative Human Cognition, $1,1-3$.

Lazar, G. (1990).Using novels in the language-learning classroom. ELT Journal, 44, 3, 204-14.

Lemke, J. L. (1985). Using Language in the Classroom. Oxford University Press.

Lemke, J. L. (1990). The language of classroom science. In C. Emihovich (Ed.), Locating Learning Across the Curriculum (pp. 216-39). Norwood, NJ: Ablex Publishing.

Leontiev, A. A. (1981). Psychology and the Language Learning Process. Oxford, U.K.: Pergamon.

Lincoln, Y., \& Guba, E. (1985). Naturalistic Inquiry. Beverly 
Hills, CA: Sage Publications.

Lightbown, Patsy (1990). Process-product research on second language learning in classrooms. In Harley et al. (Eds.), The Development of Second Language Proficiency. Cambridge University Press (82-92).

Littlewood, W. T. (1980). Form and meaning in languageteaching methodology. Language Journal, 64,4, 441-5.

Long, M. H. \& Porter, P.A. (1985). Group work, interlanguage talk, and second language acquisition. TESOL Quarterly, 19,2, 207-7.

Lottman, Y. M. (1988). Text within a text. Soviet Psychology, 26,3, 32-51.

Loureda Lamas, O. (1999). Acerca del Objeto y los Objetivos de la Ensenanza del Area de la Lengua y la Literatura en la Ensenanza Secundaria Obligatoria. RILCE, 15,2, 427-38.

Luria, A. R. (1981). Language and Cognition. J. V. Wertsch (Ed). New York: Wiley Publishing.

Lyons, J. (1977). Semantics. Cambridge University Press.

McCarthy, J. A (1998). W(h)ither literature? Reaping the fruit of language study before it's too late. ADFL Bulletin, 29,2, 10-36.

Meade, R. (1980). On teaching literature in today's world. Hispania, 63, 36-39.

Moskowitz, G. (1976). The classroom interaction of outstanding foreign language teachers. Foreign Language Annals, 9,2, 135-57.

Muyskens, J. A. \& Cassini, J. (1991). Literature in the foreign language: A comparative study. In Ervin, G. (Ed.), International Perspectives on Foreign Language Teaching (pp. 138-59). Lincolnwood, IL: NTC .

Muyskens, J. A. (1983). Teaching second language literatures: Past present and future. The Modern Language Journal, 67, 413-23.

Nunan, D. (1989). Designing tasks for the communcative classroom. Cambridge University Press.

Nunan, D. (1987). Communicative language teaching: Making it work. ELT Journal, 41,2, 136-45.

Pica, T. (1987). Second-language acquisition, social interaction, and the classroom. Applied Linguistics, 8,1, 3-21.

Pica, T., \& Long, M. (1986). The linguistic and conversational performance of experienced and inexperienced teachers. In R. Day, (Ed.), Talking to Learn. Rowley: Newbury House

Platt, E., \& Brooks, F. B. (1994). The "acquisition-rich environment" revisited. The Modern Language Journal, 78, 497-511.

Ricouer, P. (1976). Interpretation theory: Discourse and the surplus of meaning. Fort Worth, TX: Texas University Press.

Rogoff, B. (1990). Apprenticeship in thinking: Cognitive development in social context. Oxford University Press.

Rogoff, B. \& Wertsch, J.V. (Eds.) (1984). Children's Learning in the Zone of Proximal Development. San Francisco: Jossey-Bass.

Rosenblatt, L. M. (1938). Literature as Exploration. NewYork:
Modern Language Press.

Santoni, G. V. (1971). Methods of teaching literature. ACTFL Annual meeting of ACTFL. November 25-28, 1971; Chicago, IL.

Schiffrin, D. (1994). Approaches to Discourse. London: Blackwell

Smithson, J. L. (1995). Describing the Enacted Curriculum: Development and Dissemination of Opportunity to Learn Indicators in Science Education. Washington, DC: SCASS Science Project.

Spada, N. (1987). Relationships between instructional differences and learner outcomes: A process-product study of communicative language teaching. Applied Linguistics, 8,2, 137-61.

Steiner, F. (1972). Teaching literature in the secondary schools. The Modern Language Journal, 55,5, 278-83.

Steiner, F. (1970). Teaching literature by performance objectives. Foreign Language Annals, 3, 579-91.

Swaffar, J. (1998). Major changes: The standards project and the new foreign language curriculum. ADFL Bulletin, 30,1, 34-37.

Taylor, D. S. (1985). Teaching reading for comprehension in the context of English as a second or foreign language. British Journal of Language Teaching, 23,3, 163-68.

Tharp, R. G. \& Gallimore, R. (1988). Rousing Minds to Life: Teaching, Learning, and Schooling in Social Context. Cambridge University Press.

Thomas, J. J. (1998). Is there still a place for linguistics in the foreign language and literature curriculum? ADFL Bulletin, $30,1,25-29$.

Tobin, K. (1997). Dialectical constraints to the discourse practices of a high school physics community. Journal of Research in Science Teaching, 34, 491-507.

Todorov, T. (1984). Mikhail Bakhtin: The Dialogical Principal. Minneapolis: University of Minnesota Press.

Trueba, H.T. (1989). Raising Silent Voices: Educating the Linguistic Minority for the 21st Century. New York: Newbury House.

Tudge, J.(1990). Vygotsky, the zone of proximal development, and peer collaboration: Implications for classroom practice. In L. C. Moll (Ed.), Vygotsky and Education: Instructional implications and applications of sociohistorical psycholog (pp 155-72). Cambridge University Press,

Tudor, I. (1993). Teacher roles in learner-Centered classrooms. ELT Journal, 47, 1, 22-31.

Vande Berg, C. K. (1993). Managing learner anxiety in literature courses. The French Review, 67,1, 27-37

Volosinov, V. N. (1973). Marxism and the Philosophy of Language. New York: Seminar Press.

Vygotsky, L. S. (1962). Thought and Language. Cambridge, MA: MIT Press.

Vygotsky, L. S. (1978). Mind in Society. Cambridge, MA: 
Harvard University Press.

Walz, J. (1993).Context and contextualized language practice in foreign language teaching. The Modern Language Journal, 73, ii, $160-68$.

Webb, J. N. (1970). The Florida Taxonomy of Cognitive Behavior. In Simon \& Boyer (Eds.), Mirrors for Behavior, an Anthology of Classroom Observation Instruments. Philadelphia: Research for Better Schools.

Wells, G. (1999). Dialogic Inquiry: Toward Sociocultural Practice and Theory of Education. Cambridge: Cambridge University Press.

Wells, G. (1993). Reevaluating the IRF Sequence: A Proposal for the Articulation of Theories of Activity and Discourse for the Analysis of Teaching and Learning in the Classroom. Linguistics and Education, 5, 1-37.

Wertsch, J. V. (Ed.) (1986). The Concept of Activity in Soviet Psychology. Armonk, NY: Sharpe.

Wertsch, J. V. (1986). Thought and Language. Cambridge, MA: Harvard University Press.

Wertsch, J. V. ( 1991). Voices of the Mind: A Sociocultural Approach to Mediated Action. Cambridge, MA: Harvard University Press.

Wertsch, J. V. (1998). Mind as Action. Oxford University Press.

Wood,D. (1992). Teaching talk. In K. Norman (Ed.), Thinking Voices: The Work of the National Oracy Project. London: Hodder and Straughton. 


\section{Appendix A}

Florida Taxonomy of Cognitive Behavior

\author{
1.00 KNOWLEDGE OF SPECIFICS \\ 1. Reads \\ 2. Spells \\ 3. Identifies something by name \\ 4. Defines meaning of term \\ 5. Gives a specific fact \\ 6. Tells about an event \\ 7. Recognizes symbol \\ 8. Cites rule \\ 9. Gives chronological sequence \\ 10. Gives steps of process, describes method \\ 11. Cites trend \\ 12. Names classification system or standard \\ 13. Names what fits given system or standard
}

\subsection{KNOWLEDGE OF UNIVERSALS AND ABSTRACTIONS}

14. States Generalized concept or idea

15. States a principle, law, theory

16. Tells about organization or structure

17. Recalls name of principle, law, theory

\subsection{TRANSLATION}

18. Restates in own words or briefer terns

19. Gives concrete example of an abstract Idea

20. Verbalises from a graphic representation

21. Translates verabilzation into graphic form

22. Translates figurative statements to literal statements or vice versa

23. Trans from language to English, or vice versa

\subsection{INTERPRETATION}

24. Gives reason (tells why)

25. Shows similarities, differences

26. Summarizes, concludes from observation of evidence

27. Shows cause and effect relationship

28. Gives analogy, simile, metaphor

29. Performs a directed task or process

\subsection{APPLICATION}

30. Applies previous knowledge to new situation

31. Applies principle to new situation

32. Apply absract knowledge in particular situation

33. Identifies, selects, and carries out process

\subsection{ANALYSIS}

34. Distinguishes fact from opinion

35. Distinguishes fact from hypothesis fact from hypothesis

36. Distinguishes conclusion from statements which support it

37. Points out unstated assumption

38. Shows interaction or relation of elements

39. Points out particulars to justify conclusion

40. Checks hypths with given Info

41. Distinguished relevant from irrelevant statements

42. Detects error in thinking

43. Infers pupose, point of view, thoughts, feelings

44. Recognizes bias or propaganda

\subsection{SYNTHESIS (Creativity)}

45. Reorganizes ideas, materials process

46. Produces unique communication, divergent idea

47. Produces a plan, proposes a set of options

48. Designs an apparatus

49. Designs a structure

50. Devises scheme for classifying; info

51. Formulates hypothesis, intelligent guess

52. Makes deductions from abstract propositions

53. Draws inductive generalization from specifics

54. Evaluates something from evidence

55. Evaluated something from criteria 